\title{
Jurist-Diction
}

Volume 4 No. 6, November 2021

\section{Perusahaan Judi Online Sebagai Sponsor Klub Sepak Bola Profesional di Indonesia Ditinjau dari Aspek Hukum Pidana}

\author{
Annisa Gista Elfaza \\ annisagistaelfaza@gmail.com \\ Universitas Airlangga
}

How to cite:

Annisa Gista Elfaza, 'Analisis Keabsahan Pembacaan Putusan Pidana yang Dibacakan Secara Virtual atau Elektronik' (2021) Vol. 4 No. 6 Jurist-Diction.

Histori artikel:

Submit 6 April 2021;

Diterima 15 Oktober 2021;

Diterbitkan 5 November 2021.

DOI:

10.20473/jd.v4i6.31842

p-ISSN: 2721-8392

e-ISSN: $2655-8297$

\section{Abstract}

Professional sports are sports that are organized to get income from a skill. One of the most popular sport is football. In Indonesia, the Local Government Budget is not allocated to the professional football club. So, the professional football club establishes sponsorship collaboration with other agencies. For example, in league 12020 Indonesia's football competition, there was a cooperation between a professional football club with an initial "PSKB" and an online gambling site with an initial " $S$ " as a sponsorship partner. Reviewed by a criminal law aspect, it can cause a problem because there's an indication violates a positive law in Indonesia. The result of the study research showed that the club's action potentially violates Article 27 paragraph (2) Law Concerning Information and electronic transactions because the club promoted a thing aim to information about online gambling. Criminal responsibility can be imposed on the club as a corporation and/or director.

Keywords: Professional football club; Online Gambling site; Sponsorship; Social Media; Corporation.

\begin{abstract}
Abstrak
Olahraga professional merupakan olahraga yang diperuntukan untuk memperoleh pendapatan dalam bentuk uang atau lainnya atas kemaharian berolahraga. Kepopularitasan sepakbola sebagai salah satu olahraga yang digemari. Di Indonesia pendanaan sepak bola professional tidak diperoleh dari APBD, sehingga klub sepak bola professional mendapatkan dana dengan salah satu cara yaitu menjalin kerjasama sponsorship dengan pihak lain. Sebagai contohnya pada penyelenggaraan Liga 1 tahun 2020 sebagai kompetisi sepak bola, adanya kerjasama sponsorship yang dijalin antara klub sepak bola professional berinisial "PSKB" dengan situs judi online berinisial "S". Hal tersebut apabila ditinjau dari aspek hukum pidana dapat menimbulkan permasalahan dimana terdapat indikasi atau potensi melanggar aturan hukum positif di Indonesia. Hasil penelitian penulis menunjukan Perbuatan klub tersebut dapat berpotensi melanggar ketentuan Pasal 27 ayat (2) UU ITE, dikarenakan klub tersebut mempromosikan hal yang mengarah pada informasi yang memuat perjudi online. Serta, pertanggungjawaban pidananya dapat dibebankan kepada pengurus dan/atau korporasi.

Kata Kunci: Klub Sepak Bola Profesional; Situs Judi Online; Sponsorship; Sosial Media; Korporasi.
\end{abstract}

Copyright $(2021$ Annisa Gista Elfaza 


\section{Pendahuluan}

Pada Undang-Undang No. 3 Tahun 2005 Tentang Sistem Keolahragaan Nasional yang selanjutnya disebut UU Sistem Keolahragaan Nasional, berdasarkan pengertiannya olahraga dibagi menjadi beberapa macam, seperti olahraga pendidikan, olahraga rekreasi, olahraga prestasi, olahraga amatir, olahraga profesional dan olahraga penyandang cacat.

Di era sekarang ini, olahraga juga menjadi bentuk sebuah industri. Pada Pasal 1 ayat 18 UU Sistem Keolahragaan Nasional, dijelaskan mengenai industri olahraga merupakan kegiatan bisnis bidang olahraga dalam bentuk barang dan/atau jasa. Hal ini pula yang diatur pada Pasal 9 Ayat (3) Permenpora Nomor 10 Tahun 2015 jasa penjualan kegiatan cabang olahraga meliputi salah satunya kejuaraan nasional dan internasional.

Sebagai contohnya perusahaan yang bergerak pada bidang industri olahraga di Indonesia yang menyelenggarakan kompetisi adalah PT LIB atau PT Liga Indonesia Baru yang merupakan perusahaan penyelenggara kompetisi sepak bola di Indonesia. Dalam kompetisi yang diselenggarakan PT LIB, terdapat beberapa klub sepak bola di Indonesia yang tergabung dalam kompetisi tersebut. Di awal tahun 2020, PT LIB menyelenggarakan dua kompetisi liga sepak bola Indonesia yaitu Shopee Liga 12020 dan Liga 2 2020. Menurut artikel dalam situs resmi PSSI, Liga 2 yang sebelumnya disebut sebagai Divisi Utama atau Satu Liga Indonesia merupakan liga kasta ke-2 dalam Liga Indonesia, yang posisinya berada dibawah Liga $1 .{ }^{1}$

Diketahui pada website resmi PT LIB, pada kompetisi Liga 12020 terdapat delapan klub yang bergabung dalam kompetisi tersebut, diantaranya seperti Arema FC, Bali United, Barito Putera, PS Tira yang kemudian berganti nama menjadi Persikabo 1973, Persita Tangerang, PSIS Semarang, PSM Makassar, PSS Sleman, dan lain sebagainya.

Liga 1 merupakan liga yang dilaksanakan dengan mengikuti persyaratan FIFA, yang menyatakan bahwa liga teratas dari suatu negara harus diikuti oleh

${ }^{1}$ [s.n], 'Liga 2', <https://ligaindonesia.id/clubs?competition=shopee_liga_1_2020> accesed 19 November 2020. 
minimal 18 (delapan belas) klub dan setiap klubnya merupakan klub profesional tanpa dibantu dana Anggaran Pendapatan Dan Belanja Daerah (APBD). Sehingga, klub-klub yang mengikuti liga 12020 yang telah disebutkan sebelumnya merupakan badan hukum. Berdasarkan ketentuan Pasal 70 UU Sistem Keolahragaan Nasional, pendanaan keolahragaan dapat diperoleh dari beberapa hal, diantaranya dari masyarakat melalui berbagai kegiatan, kerja sama yang saling menguntungkan, bantuan luar negeri yang tidak terikat, hasil industri olahrga atau sumber lain yang sah menurut undang-undang. ${ }^{2}$

Dikarenakan hal tersebut maka banyak klub sepak bola yang melakukan kerja sama Sponsorship. Pada kompetisi Liga 1 2020, klub sepak bola professional di Indonesia berinisial "PSKB" tersebut terlihat menjalin perjanjian kerja sama sponsorship dengan situs perjudian online yang berinisial "S". Sebagai feedback, nama situs perjudian online tersebut dicantumkan pada jersey mereka yang digunakan dalam pertandingan atau kompetisi Liga $12020{ }^{3}$

Dilansir dari laman situs judi online berinisial "S" tersebut, situs tersebut merupakan produk perusahaan "online gaming", dan merupakan bagian dari perusahaan besar yang telah diakui di seluruh industri taruhan Global. PT LIB selaku penyelenggara liga kemudian menerbitkan Surat Edaran Nomor 103/LIB/II/2020 yang dikeluarkan pada tanggal 25 Februari 2020 dengan tujuan pelarangan sponsor situs judi, rokok dan alkohol untuk klub-klub yang mengikuti Liga 1 dan Liga 2. Namun, hingga saat ini meskipun telah dikeluarkannya surat tersebut, klub sepak bola professional berinisial "PSKB" masih menggunakan rumah judi sebagai sponsornya.

Hingga saat ini, perjudian dianggap sebagai perbuatan terlarang bahkan dikategorikan sebagai perbuatan pidana dalam sistem hukum Indonesia. Perbuatan pidana merupakan perbuatan yang dilarang oleh suatu aturan hukum larangan dan disertai ancaman pidana tertentu kepada siapapun yang melanggar larangan tersebut. ${ }^{4}$

\footnotetext{
${ }^{2}$ Undang-Undang Nomor 3 Tahun 2005 Tentang Sistem Keolahragaan Nasional (Lembaran Negara Republik Indonesia Tahun 2005 Nomor 89).

${ }^{3}$ Zulfirdaus Harahap, 'Disponsori Situs Judi, Ini Tanggapan Tira Persikabo', ([s.1],2020), $<$ www.liputan6.com $>$, accesed 03 September 2020.

${ }^{4}$ Mahrus Ali, Dasar-Dasar Hukum Pidana: Cetakan Ketiga (Sinar Grafika 2015).[97].
} 
Timbal balik yang diberikan oleh klub sepak bola professional di Indonesia berinisial "PSKB" dalam kerja sama nya dengan situs judi online berinisial "S" tersebut dikhawatirkan dapat membuat konsumen media, khususnya supporter bola "PSKB" memiliki kecendurangan untuk mengakses situs perjudian online khususnya situs judi online yang berinisial " $S$ " tersebut. Hal ini juga dapat memicu angka transaksi perjudian online yang berbanding terbalik dengan semangat Pemerintah Republik Indonesia untuk membrantas perjudian. Perbuatan Klub sepak bola professional berinisial "PSKB" tersebut dapat mengakibatkan dapat diaksesnya informasi mengenai perjudian maka hal ini tentunya juga diatur dalam UU ITE, namun perbuatan dapat diaksesnya dalam UU ITE memiliki pengertian yang sangat luas dan tidak ada Batasan perbuatan yang jelas, hal ini tentunya dapat menjadi kekaburan norma.

Perjanjian kerja sama sponsorship antara klub sepak bola professional "PSKB" dan situs perjudian online berinisial " $S$ " tersebut, dapat berpotensi sebagai masalah hukum, dikarenakan aturan mengenai perjudian diatur dalam hukum positif Indonesia dan bahkan diancam pidana. Aturan perjudian pada mulanya diatur dalam Kitab Undang-Undang Hukum Pidana (KUHP) yang kemudian terdapat UndangUndang Nomor 7 Tahun 1974 Tentang Penertiban Perjudian, dan perjudian yang dilakukan secara daring atau online diatur dalam Undang-Undang Nomor 11 Tahun 2008 jo. Undang-Undang Nomor 19 Tahun 2016 tentang Informasi dan Transaksi Elektronik atau yang dapat disebut UU ITE.

Terdapat dua subjek hukum dalam hukum publik atau pidana, yaitu subjek hukum orang dan korporasi. Klub sepak bola merupakan subjek hukum yang berbentuk korporasi, hal ini dikarenakan klub sepak bola memiliki kekayaan yang terpisah, memiliki tujuan tertentu, dan berkesinambungan. korporasi masih belum di atur dalam Kitab Undang-Undang Hukum Pidana (KUHP), namun beberapa peraturan di Indonesia mulai mengadopsi dan mengatur korporasi sebagai subjek yang dapat melakukan tindak pidana dan dikenai sanksi berdasarkan undang-undang yang mengaturnya. Sehingga, penulis tertarik untuk meniliti dan menganalisis lebih lanjut mengenai pasal yang dapat diterapkan pada situs judi online sebagai 
sponsorship klub sepak bola di Indonesia yang mengarah pada tindak pidana.

Berdasarkan uraian diatas, penulis tertarik untuk meneliti isu hukum dari permasalahan tersebut yang dirumuskan sebagai klasifikasi tindak pidana sepak bola professional di Indonesia yang membuat dapat diaksesnya informasi mengenai situs judi online melalui sponsor dan pertanggungjawaban pidana klub sepak bola di Indonesia yang membuat dapat diaksesnya informasi mengenai situs judi online sebagai sponsor.

\section{Klub Sepak Bola Professional di Indonesia yang Membuat Dapat Diaksesnya Informasi Mengenai Situs Judi Online Melalui Kerjasama Sponsorship}

Perjudian merupakan permainan dimana para pemainnya bertaruh untuk memilih satu pilihan diantara beberapa pilihan yang kemudian hanya satu yang pilihan yang benar dan menjadi pemenang. Lalu, pemain yang kalah akan memberikan taruhannya kepada pemain yang menang. Untuk berapa besar jumlah taruhan serta peraturannya ditentukan sebelum dimulainya pertandingan.

Di Indonesia, praktik perjudian merupakan kegiatan yang dilarang oleh undang-undang. Dalam peraturan perundang-undangan Indonesia Tindak pidana perjudian biasa diatur dalam Pasal 303 KUHP (Kitab Undang-Undang Hukum Pidana) sedangkan tindak pidana perjudian dalam jaringan diatur dalam Pasal 27 ayat (2) UU No. 19 Tahun 2016 tentang Perubahan Atas UU No. 11 Tahun 2008 Tentang Informasi dan Transaksi Elektronik (UU ITE). ${ }^{5}$

Larangan perjudian diatur dalam Wetboek van Strafrecht (WvS) atau merupakan Kitab Undang-Undang Hukum Pidana (KUHP) yang mengatur mengenai perbuatan pidana yang hingga saat ini berlaku di Indonesia. Larangan perjudian termuat pada Pasal 303 KUHP, dan Pasal 542 KUHP. Munculnya Undang-Undang Nomor 7 Tahun 1974 Tentang Penertiban Perjudian kemudian merubah ketentuan yang ada pada Pasal 303 KUHP dan 542 KUHP diantaranya merubah ancaman hukuman pada Pasal 303 ayat (1) KUHP, merubah hukuman dalam pasal 542 ayat

\footnotetext{
${ }^{5}$ Muhammad Fajrul Falah, Fanny Tanuwijaya, Samuel SM Samosir, 'Perjudian Online: Kajian Pidana atas Putusan Nomor 1033/PID.B/2014/PN.BDG' (2017) 4 e-journal Lentera Hukum.[34].
} 
(1) KUHP, serta merubah Pasal 542 KUHP menjadi Pasal 303 bis. Undang-Undang ini juga menyatakan bahwa semua tindak pidana perjudian merupakan kejahatan

Sehingga, dengan adanya ketentuan pada Undang-Undang Nomor 7 Tahun 1974 Tentang Penertiban Perjudian, maka pengaturan pada Pasal 303 ayat (1), (2) dan (3) KUHP kemudian bebunyi sebagai berikut: ${ }^{6}$

(1) Diancam pidana penjara paling lama sepuluh tahun atau pidana denda paling banyak dua puluh lima juta rupiah barang siapa tanpa mendapat izin:

1. Dengan sengaja menawarkan atau memberikan kesempatan untuk permainan judi dan menjadikannya sebagai pencarian, atau dengan sengaja menawarkan atau memberikan kesempatan untuk permainan judi dan menjadikannya sebagai pencarian, atau dengan sengaja turut serta dalam suatu perusahaannya untuk itu;

2. Dengan sengaja menawarkan atau memberi kesempatan kepada khalayak umum untuk bermain judi atau dengan sengaja turut serta dalam perusahaan untuk itu, dengan tidak peduli apakah untuk menggunakan kesempatan adanya sesuatu syarat atau dipenuhinya suatu tata cara;

3. Menjadikan turut serta pada permainan judi sebagai pencarian.

(2) Jika yang bersalah melakukan kejahatan tersebut dalam menjalankan pencariannya, maka dapat dicabut haknya untuk menjalankan pencarian itu.

(3) Yang disebut permainan judi adalah tiap-tiap permainan, dimana pada umumnya kemungkinan mendapat untung bergantung pada peruntungan belaka, juga karena pemainnya lebih terlatih atau mahir. Disitu termasuk segala pertaruhan tentang keputusan perlombaan atau permainan lain-lainnya yang tidak diadakan antara mereka yang turut berlomba atau bermain, demikian juga segala pertaruhan lainnya.

${ }^{6}$ Kitab Undang-Undang Hukum Pidana (Wetboek van Strafrech) (atas pemberlakuan UndangUndang Nomor 73 Tahun 1958 Tentang Menyatakan Berlakunya Undang-Undang Nomor 1 Tahun 1946 Republik Indonesia Tentang Peraturan Hukum Pidana Untuk Seluruh Wilayah Republik Indonesia, Dan Mengubah KUHP(Lembaran Negara 1958, Tambahan Lembaran Negara1660). 


\section{Pasal 303 bis}

(1) Diancam dengan pidana penjara paling lama empat tahun atau pidana denda paling banyak sepuluh juta rupiah: ${ }^{7}$

1. Barang siapa menggunakan kesempatan main judi, yang diadakan dengan melanggar ketentuan Pasal 303;

2. Barang siapa ikut serta main judi di jalanan umum atau pinggir jalan umum atau ditempat yang dapat dikunjungi umum, kecuali jika ada izin dari penguasa yang berwenang yang telah memberi izin untuk mengadakan perjudian itu.

(2) Jika Ketika melakukan pelanggaran belum lewat dua tahun sejak ada pemidanaan yang tetap karena salah satu dari pelanggaran ini, dapat dikenakan pidana penjara paling lama enam tahun atau pidana denda paling banyak lima belas juta rupiah.

Sedangkan mengenai pengertian perjudian dijelaskan pada Pasal 303 ayat (3) KUHP, yang memiliki rumusan: ${ }^{8}$

a) Tiap-tiap permainan, yang pada umumnya kemungkinan mendapat untung bergantung pada peruntungan belaka, juga karena pemainnya lebih terlatih atau mahir.

b) Segala pertaruhan tentang keputusan perlombaan permainan lainnya yang tidak diadakan antara mereka yang turut berlomba atau bermain

c) Segala pertaruhan lainnya,

Setelah Adanya Pasal 1 ayat (1) PP No. 9 Tahun 1981 Tentang Penertiban Perjudian, yang mengatur mengenai pemberian izin penyelenggaraan segala bentuk serta jenis perjudian dilarang, baik perjudian yang diselenggarakan di kasino, di tempat keramaian maupun yang dikaitkan dengan alasan lainnya. ${ }^{9}$ Maka, pemberian izin dari penguasa mengenai perbuatan perjudian merupakan hal yang dilarang dalam peraturan pemerintah ini.

Pasal 303 ayat (1) KUHP memiliki beberapa kejahatan, yang diantaranya apabila diuraikan unsur-unsurnya adalah:

${ }^{7}$ ibid.

${ }^{8}$ Claudio Gideon Wagey, Ruddy R. Watulingas, Roy R. Lembong, 'Penertiban Perjudian Menurut Peraturan Perundang-Undangan Pidana Indonesia (Analisis Pasal 303 KUHPidana jo. UU No. 7 Tahun 1974)' (2020) 9 Lex. Crimen.[73]

${ }_{9}$ Peraturan Pemerintah Nomor 9 Tahun 1981 Tentang Pelaksanaan Penertiban Perjudian (Lembaran Negara Republik Indonesia Tahun 1981 Nomor 10, Tambahan Lembaran Negara Nomor 3192). 
1. Pasal 303 ayat (1) ke-1 KUHP yang memiliki dua unsur yaitu: unsur subjektif "dengan sengaja" dan unsur objektif "menawarkan atau memberi kesempatan untuk permainan judi dan menjadikan sebagai pencarian atau turut serta dalam suatu usaha perusahaan". ${ }^{10}$

Unsur subjektif tersebut harus dibuktikan dengan adanya kehendak atau maksud untuk secara sengaja menawarkan atau memberikan kesempatan bermain judi sebagai usaha, adanya kehendak atau maksud untuk menawarkan atau memberi kesempatan bermain judi serta diketahuinya oleh pelaku bahwa apa yang ditawarkan atau kesempatan yang diberikan tersebut adalah untuk permainan judi. ${ }^{11}$

Sedangkan unsur objektif yang pertama yaitu menawarkan atau memberi kesempatan untuk permainan judi, dalam unsur ini pelaku harus terbukti melakukan perbuatan berbentuk lisan maupun tulisan yang tidak memiliki izin oleh pihak berwenang yang memuat penawaran atau memberikan kesempatan terhadap orang lain untuk bermain judi. ${ }^{12}$

Unsur objektif yang kedua adalah menjadikan sebagai pencaharian atau turut serta dalam suatu usaha sebuah perusahaan judi. ${ }^{13}$ dalam unsur ini pelaku harus merupakan orang yang terbukti menawarkan atau memberikan kesempatan kepada seseorang untuk bermain judi secara terus menerus dengan tujuan perusahaan tersebut mendapatkan keuntungan materiil. ${ }^{14}$ Selain itu, turut serta dalam suatu perusahaan merupakan perbuatan dengan menyediakan keuangan, membina atau meningkatkan pendirian usaha judi. ${ }^{15}$ Patut diketahui disini bahwa, unsur menawarkan dan memberikan kesempatan berarti si pembuat melakukan apa saja agar orang-orang bermain judi, dengan

\footnotetext{
${ }^{10}$ Imam Dwi Wahyudi, 'Pertanggungjawaban Pidana Pemilik Website Atas Judi Online Ditinjau Dari Undang-Undang Nomor 11 Tahun 2008 Tentang Informasi dan Transaksi Elektronik', (Skripsi Program Studi Hukum Pidana Fakultas Universitas Islam Bandung 2014).[63].

${ }^{11}$ ibid.

${ }^{12}$ ibid.

${ }^{13}$ ibid.

${ }^{14}$ ibid.

15 ibid.
} 
menyediakan tempat atau waktu tertentu, namun dalam hal ini belum ada orang yang bermain judi. ${ }^{16}$

2. Pasal 303 ayat (1) ke-2 KUHP

Dalam pasal ini terdiri dari dua unsur, yaitu unsur subjektif "dengan sengaja" dan unsur obketif "menawarkan atau memberi kesempatan kepada khalayak umum untuk permainan judi atau turut serta dalam perusahaan”.

Dalam pasal tersebut perbuatan yang dikatakan dapat memenuhi unsur subjektif "dengan sengaja" sama dengan yang telah dijelaskan sebelumnya pada unsur Pasal 303 ayat (1) ke-1 KUHP. Unsur objektif yaitu perbuatan "menawarkan atau memberi kesemapatan” juga memiliki pengertian yang sama dengan Pasal 303 ayat (1) ke-1 KUHP. Pembeda larangan dalam pasal ini adalah objek yang dituju yaitu "kepada kahlayak umum". Perbedaan dengan kejahatan sebelumnya, pada kejahatan sebelumnya perbuatan menawarkan atau memberikan kesempatan tidak disebutkan kepada siapa objek yang dituju bisa seseorang atau beberapa orang, sedangkan dalam pasal ini disebutkan "khalayak umum" yang berarti secara umum bukan satu atau beberapa orang saja. ${ }^{17}$

Sedangkan, perbedaan unsur "turut serta dalam kegiatan usaha permainan judi tanpa izin" dengan Pasal 303 ayat (1) ke-1 KUHP adalah turut serta ini tidak ditujukan untuk mata pencaharian. ${ }^{18}$

3. Pasal 303 ayat (1) ke-3 KUHP yaitu "turut serta pada permainan judi sebagai pencarian", turut serta yang dimaksud disini adalah bukan turut serta dalam menawarkan atau memberi kesempatan bermain judi namun pelaku turut serta bermain judi sebagai bentuk mata pencahariannya.

Dikaitkan dengan perbuatan klub sepak bola professional di Indonesia berinisial "PSKB" yang mengekspos situs judi online berinsial "S" sebagai bentuk kerjasama sponsorship, tidak dapat dikatakan memenuhi Pasal

\footnotetext{
${ }^{16}$ Geraldy Waney, 'Kajian Hukum Terhadap Tindak Pidana Perjudian (Penerapan Pasal 303, 303 BIS KUHP)’ (2016) 5 Lex Crimen.[34].

${ }^{17}$ ibid.

18 ibid.
} 
303 KUHP. Hal ini dikarenakan, klub sepak bola professional berinisial "PSKB" tersebut tidak memenuhi unsur objektif "menawarkan atau memberi kesempatan”. Klub tersebut tidak menawarkan secara langsung permainan judi, serta tidak memberi kesempatan kepada seseorang atau khalayak umum untuk bermain judi dalam artian tidak menyediakan waktu atau tempat bermain judi. Klub sepak bola professional berinisial "PSKB" tersebut, juga tidak turut serta atau terlibat secara langsung didalam kegiatan usaha perusahaan dalam menawarkan atau memberi kesempatan bermain judi, serta tidak menjadikan hal tersebut sebagai mata pencaharian.

Selain pengaturan pada KUHP, pengaturan perjudian sebagai tindak pidana diatur juga pada Undang-Undang Republik Indonesia Nomor 19 Tahun 2016 Tentang Perubahan Atas Undang-Undang Nomor 11 Tahun 2008 Tentang Informasi Dan Transaksi Elektronik atau bisa disebut sebagai UU ITE. Dalam UU ITE mengatur mengenai segala yang berhubungan dengan perjudian dalam jaringan atau judi online. UU ITE merupaka perwujudan dari asas lex specialis derogate legi generalis dari ketentuan yang ada dalam KUHP.

Ketentuan asas lex specialis derogate legi generalis terkandung pada Pasal 63 ayat (2) KUHP, yang merupakan penafsiran hukum bahwa ketentuan yang lebih khusus mengkesampingkan ketentuan yang lebih umum. ${ }^{19}$ Ketentuan mengenai perjudian pada UU ITE termuat dalam Pasal 27 ayat (2) UU ITE dan ketentuan pidananya termuat dalam Pasal 45 ayat (2) UU ITE.

Pada pasal 27 ayat (2) UU ITE disebutkan mengenai perbuatan-perbuatan yang dilarang, pasal tersebut berbunyi: ${ }^{20}$

"Setiap orang yang dengan sengaja atau tanpa hak mendistribusikan dan/atau mentransmisikan dan/atau membuat dapat diaksesnya informasi elektronik dan/atau dokumen elektronik yang memiliki muatan perjudian".

\footnotetext{
${ }^{19}$ Peter Mahmud Marzuki, Penelitian Hukum (Kencana Prenada Media Group 2014).[141].

${ }^{20}$ Undang-Undang Nomor 11 Tahun 2008 Tentang Informasi dan Transaksi Elektronik (Lembaran Negara Tahun 2008 Nomor 58, Tambahan Lembaran Negara Nomor 4843).
} 
Pasal 27 ayat (2) UU ITE memiliki beberapa unsur diantaranya: ${ }^{21}$

- Unsur subjektif : Dengan sengaja

- Unsur melawan hukum : Tanpa hak

- Perbuatan : Mendistribusikan dan/atau mentransmisikan dan/atau membuat dapat diaksesnya

- Objek : Informasi elektronik dan/atau dokumen elektronik yang memiliki muatan perjudian.

Pada Pasal 45 ayat (2) UU ITE disebutkan mengenai ancaman pidana setiap orang yang melakukan perbuatan sebagaimana diatur pada Pasal 27 ayat (2) UU ITE. Pasal tersebut berbunyi: ${ }^{22}$

"Setiap Orang yang dengan sengaja dan tanpa hak mendistribusikan dan/atau mentransmisikan dan/atau membuat dapat diaksesnya Informasi Elektronik dan/atau Dokumen Elektronik yang memiliki muatan perjudian sebagaimana dimaksud dalam Pasal 27 ayat (2) dipidana dengan pidana penjara paling lama 6 (enam) tahun dan/atau denda paling banyak Rp1.000.000.000,00 (satu miliar rupiah)".

Dalam Pasal tersebut subjek yang disebutkan adalah "setiap orang” dimana definisinya mengancu pada ketentuan Pasal 1 angka 21 UU ITE yaitu orang adalah perseorangan baik warga negara Indonesia, warga negara asing, maupun badan hukum. ${ }^{23}$

Unsur kedua pada Pasal 27 ayat (2) UU ITE yaitu dengan sengaja. Kesengajaan merupakan salah satu bentuk dari kesalahan, dengan sengaja atau dapat disebut opzet merupakan keadaan dimana seseorang dianggap sengaja telah menghendaki perbuatan itu dan mengetahui, menginsyafi, atau mengerti akibatnya dari perbuatan tersebut. ${ }^{24}$ Dalam Memorie van Toelichting, kata "dengan sengaja" adalah sama dengan "willens en wetens" atau dikehendaki dan diketahui. unsur melawan hukum pada Pasal 27 ayat (2) yaitu Tanpa hak. Tanpa hak pada pasal ini merupakan tidak memiliki kekuasaan untuk berbuat sesuatu yang apabila dikaitkan dengan pasal ini

\footnotetext{
${ }^{21}$ Adami Chazawi, Ardi Ferdian, Tindak Pidana Informasi \& Transaksi Elektronik(Penyerangan Terhadap Kepentingan Hukum Pemanfaatan Teknologi Informasi Dan Transaksi Elektronik) edisi revisi (Media Nusa Creative 2015). [5].

${ }^{22}$ Op.Cit.

${ }^{23}$ Devy Suciati, Supanto, 'Pengaturan Judi Bola Online Sebagai Tindak Pidana Siber Dalam Hukum Pidana Di Indonesia’(2015) 4 Recidive.[178].

${ }^{24}$ ibid.
} 
yaitu tidak memiliki kekuasaan untuk berbuat sesuatu untuk mendistribusikan dan/ atau mentransmisikan dan/atau membuat dapat diaksesnya informasi elektronik dan/atau dokumen elektronik yang memiliki muatan perjudian. ${ }^{25}$ Sedangkan, mendistribusikan", "mentransmisikan" dan "membuat dapat diaksesnya" dijelaskan dalam Penjelasan Pasal 27 ayat (1) UU ITE.

Penafsiran unsur "membuat dapat diakses" apabila dirumuskan secara abstrak adalah segala wujud kegiatan yang berpengaruh pada tersalurnya atau terhubung kepada dokumen dan/atau informasi elektronik. ${ }^{26}$ Dokumen dan/atau informasi elektronik dalam kaitannya pada hal ini adalah mengenai perjudian.

Apabila dicermati dalam unsur "membuat dapat diakses" Pada Pasal 27 UU ITE, yang tidak memiliki Batasan perbuatan secara tegas maka hal ini dapat menimbulkan multitafsir atau dapat terbuka berbagai macam tafsir mengenai perbuatan apa yang termasuk sebagai "segala perbuatan lain selain mendistribusikan dan mentransmisikan melalui sistem elektronik yang dapat mengakibatkan informasi dan/atau dokumen elektronik diketahui oleh publik". Adanya ketidak jelasan rumusan perbuatan pidana yang dapat menimbulkan multitafsir dapat membahayakan kepastian hukum.

Unsur objek pada Pasal 27 ayat (2) UU ITE adalah Informasi elektronik dan/ atau dokumen elektronik yang memiliki muatan perjudian. mengenai informasi elektronik pengertiannya mengacu dalam Pasal 1 angka 1 UU ITE dan dokumen elektronik yang pengertiannya mengacu pada Pasal 1 angka 4 UU ITE. Sedangkan, dikaitkan dengan "yang memiliki muatan perjudian" berarti segala informasi elektronik dan/atau dokumen elektronik yang didalamnya terkandung muatan perjudian, dimana perjudian tersebut pengertiannya tetap mengacu pada Pasal 303 ayat (3) KUHP.

Apabila dikaitkan dengan tindakan klub sepak bola professional berinisial "PSKB”, maka Unsur pertama yang termuat dalam pasal 27 ayat (2) jo. Pasal 45

\footnotetext{
${ }^{25}$ ibid.

${ }^{26}$ Ayya Sofia Istifarrah, 'Pertanggungjawaban Pidana Pelaku Pendistribusian Konten Yang Bermuatan Asusila Melalui Media Elektronik’ (2020) 3 Jurist-Diction.[1508].
} 
ayat (2) UU ITE yaitu dengan sengaja, dengan sengaja merupakan unsur melawan hukum dalam rumusan pasal ini. Dengan adanya kehendak klub sepak bola professional berinisal "PSKB" yang mengekspos situs judi online berinisal " $\mathrm{S}$ " pada website dan sosial media klub merupakan hal yang dilakukan secara sadar dikarenakan tindakan tersebut merupakan perwujudan dari perjanjian kerjasama sponsorship.

Unsur berikutnya adalah tanpa hak yang diartikan sebagai tidak adanya wewenang atau perbuatannya itu bertentangan dengan peraturan perundangundangan atau hukum yang berlaku serta tidak adanya izin dari pihak berwenang. ${ }^{27}$ Mengingat pada Pasal 1 ayat(1) PP No. 9 Tahun 1981 tentang Pelaksanaan Penertiban Perjudian yang melarang adanya pemberian izin penyelenggaraan segala bentuk dan jenis perjudian, maka dihubungkan dengan tindakan klub sepak bola berinisial "PSKB" yang mengekspos situs judi online berinisial "S" pada website dan sosial media klub serta didasari oleh perjanjian kerjasama sponsorship tanpa persetujuan pihak yang berwenang, maka unsur tanpa hak tersebut terpenuhi.

Unsur berikutnya adalah perbuatan mendistribusikan dan/atau mentransmisikan dan/atau membuat dapat diaksesnya informasi dan/atau dokumen elektronik yang bermuatan perjudian. Arti dan/atau dalam pasal tersebut bukan berarti tiga perbuatan tersebut adalah sama, perbuatan tersebut dapat terjadi serentak atau dapat terjadi salah satu saja. ${ }^{28}$

Merujuk pada tindakan klub sepak bola professional berinisial "PSKB" yang mengekspos situs judi online berinisial "S" pada website resmi klub, serta unggahan yang berkaitan dengan situs judi online tersebut dengan memuat keterangan yang mengajak para pembaca untuk mengunjungi sosial media situs judi online berinisial "S". Termuat pula didalam sosial media itu beberapa iklan atau unggahan ajakan permainan judi. Maka, unsur "membuat dapat diaksesnya" dapat terpenuhi dikarenakan tindakan klub yang melakukan segala tindakan atau perbuatan yang terhubung pada sosial media situs judi online berinisial "S" yang didalamnya

\footnotetext{
${ }^{27}$ Muhammad Fajrul Falah, Fanny Tanuwijaya, Samuel SM Samosir, Op.Cit.[35]

${ }^{28}$ ibid.
} 
termuat informasi memgenai perjudian, serta perbuatan tersebut secara tidak langsung membuat publik mengetahui informasi mengenai permainan perjudian online pada sosial media perusahaan judi online berinisial "S".

Unsur subjek dalam Pasal 27 ayat (2) UU ITE yaitu Setiap orang, definisi orang pada Pasal 1 angka 23 UU ITE adalah perseorangan atau badan hukum, sehingga dengan adanya definisi ini maka pemidanaan terhadap korporasi adalah hal yang dimungkinkan. Klub sepak bola professional berinsial "PSKB" yang berbentuk badan hukum dapat dikenai pertanggungjawaban pidana berdasarkan undang-undang ini.

Definisi sponsorship adalah kegiatan yang dijalin oleh individu maupun badan usaha yang melakukan kerjasama melalui perjanjian dengan memberikan dana atau barang dengan perusahaan atau individu lain untuk melaksanakan kegiatan maupun acaranya dengan tujuan pemberi sponsor juga mendapatkan manfaat atau keuntungan komersil dari acara tersebut.

Terdapat beberapa jenis sponsor berdasarkan tujuannya. seperti sponsor untuk iklan, sponsor untuk mendukung usaha perusahaan, sponsor untuk mendukung usaha peursahaan dan sponsor untuk menunjang usaha-usaha public relations. ${ }^{29}$

Dari definisi yang telah diuraikan tersebut dapat mengartikan bahwa sponsorship merupakan hasil dari bentuk perjanjian kerjasama dua pihak yang mengikatkan diri sesuai dengan tujuan dilakukannya kegiatan sponsorship. Pengaturan mengenai perjanjian sponsorship mengacu pada burgelijk wetboek atau yang dapat disebut BW, lebih khusus mengenai aturan-aturan yang lahir dari suatu perjanjian. Sehingga segala aturan dasar perjanjian tunduk pada aturan yang termuat dalam BW. Hal ini berarti, pengertiannya pula mengacu pada definisi perjanjian sebagaimana Pasal 1313 BW yaitu suatu perbuatan yang mana satu orang atau lebih mengikatkan dirinya terhadap satu orang atau lebih.

Mengenai perjanjian sponsorship, terdapat beberapa asas yang mendasari perjanjian yang disepakati oleh para pihak. Yaitu Asas kebebasan berkontrak, Asas 
konsensualisme, Asas pacta sunt servanda, Asas itikad baik, Asas kepribadian atau personalitas dan Asas kepercayaan.

Penggunaan dana APBD untuk klub sepak bola professional adalah hal yang dilarang, terlebih pada klub-klub professional yang berstatus badan hukum dalam hal ini Perseroan Terbatas (PT) dikarenakan merujuk pada Undang-Undang Nomor 40 Tahun 2007 tentang Perseroan Terbatas yang seharusnya bersifat mandiri dan berorientasi profit. ${ }^{30} \mathrm{Hal}$ ini kemudian dipertegas melalui Surat Edaran Menteri Dalam Negeri Nomor 978/753/SJ tertanggal 06 Februari 2017 tentang Peningkatan Pembinaan dan Pengembangan Olahraga di Daerah, yang mempertegas bahwa alokasi APBD tidak diperuntukkan untuk pendanaan olahraga professional sesuai dengan amanat UU Sistem Keolahragaan Nasional.

Merujuk pada Peraturan Pemerintah Nomor 18 Tahun 2007 Tentang Pendanaan Keolahragaan, pengaturan mengenai sumber pendanaan diatur pada BAB II Peraturan Pemerintah ini, salah satu kegiatan yang dapat dilakukan adalah dengan menjalin kerjasama sponsorship. Sesuai dengan pengertian sebelumnya, bahwa kerjasama sponsorship yang dituangkan dalam perjanjian kerjasama sponsorship dalam hal ini klub sepak bola professional dengam pihak lainnya harus memperhatikan aspek-aspek perjanjian pada BW.

Klub sepak bola professional di Indonesia dengan insial "PSKB" yang menggandeng perusahaan perjudian "S" untuk menjalin kerja sama sponsorship pada liga 1 2020. Seperti yang telah diuraikan pada sub bab sebelumnya, bahwa pada kerjasama sponsorship yang dituangkan dalam sebuah perjanjian terdapat ketentuan-ketentuan yang disepakati oleh para pihak. Sesuai dengan tujuan kerjasama sponsorship adalah meningkatkan brand awareness serta image sebuah perusahaan pemberi sponsor, dan penerima sponsor mendapatakan uang, barang atau jasa yang digunakan untuk menunjang kegiatannya.

Penulis menganalisis beberapa kegiatan yang dilakukan oleh klub sepak bola professional di Indonesia berinisial "PSKB" dalam memenuhi

\footnotetext{
${ }^{30}$ Eko Noer Kristiyanto, 'Mengapa APBD bukan untuk Klub sepak bola professional?' (2016) Rechtsvinding online.[1].
} 
kontraprestasi dengan perusahaan judi online berinisial " $\mathrm{S}$ ". Beberapa diantaranya adalah, seperti memasang logo situs judi online pada jersey klub, website dan sosial media sebagai sponsor yang ditujukan untuk memperkuat brand perusahaan judi di Indonesia, serta klub juga mempromosikan kegiatan yang diselenggarakan oleh perusahaan judi online tersebut pada website klub pada bagian sponsor dan pada sosial media klub dengan keterangan pada unggahan yang mengajak pembaca untuk mengunjungi sosial media milik perusahaan judi online berinisial S.

Klub mempromosikan beberapa kegiatan mengenai perusahaan judi online dengan klub, yaitu seperti kegiatan perlombaan atau give away dengan syarat untuk mengikutinya adalah "follow" sosial media dari perusahaan judi, dimana apabila pembaca dari kegiatan tersebut semakin banyak "follow" sosial media dari perusahaan judi maka akan memperbesar kesempatan untuk menang. Hal ini apabila dicermati, Ketika pembaca mengikuti sosial media dari perusahaan judi yang berasal dari kegiatan tersebut maka secara berkala akan terdapat informasi mengenai perjudian online yang diselenggarakan oleh perusahaan. Hal ini tentunya klub membuat dapat diaksesnya informasi mengenai perjudian secara terselubung dalam promosi tersebut.

\section{Pertanggung Jawaban Pidana Para Pihak}

Apabila didasarkan pengertian korporasi secara etimologi, korporasi berasal dari Bahasa latin yaitu "corporation" sebagai bentuk kata benda dari kata kerja "corporare" yang berarti badan atau membadankan dan berasal dari kata "corpus" yang berarti badan. Secara terminologi, corporation tersebut diartikan sebagai badan yang dijadikan orang. ${ }^{31}$

Beberapa ahli memberikan pengertian korporasi, seperti E. Utrecht yang memaknai korporasi sebagai gabungan orang yang dalam pergaulan hukum bertindak bersama-sama sebagai subjek hukum sendiri sebagai suatu personifikasi.

${ }^{31}$ Soetan K. Malikoel Adi, Pembaruan Hukum Perdata Kita, (PT Pembangunan 1955).[83]. 
Korporasi merupakan badan hukum yang beranggota namun memiliki hak dan kewajiban sendiri diluar hak dan kewajiban anggotanya. ${ }^{32}$

Perkembangan korporasi sebagai subjek hukum pidana juga terjadi di Indonesia, korporasi diakui sebagai subjek hukum korporasi dimulai pada Tahun 1951 yaitu ditandai dengan adanya Undang-Undang Penimbunan Barang-barang, yang kemudian diikuti beberapa undang-undang lainnya. Namun, subjek hukum pidana korporasi tidak diatur dalam Kitab Undang-Undang Hukum Pidana (KUHP) dikarenakan pada KUHP masih mengatur subjek hukum pidana adalah manusia sesuai pada Pasal 59 KUHP. Pengaturan mengenai subjek hukum pidana korporasi di Indonesia ditemui dalam Undang-undang khusus diluar KUHP. ${ }^{33}$

Berkaitan dengan kedudukan sebagai sifat serta pembuat mengenai pertanggungjawaban pidana korporasi, beberapa model pertanggungjawaban korprorasi diantaranya adalah:

1. Pengurus korporasi sebagi pembuat dan pengurus tersebut yang bertanggungjawab;

2. Korporasi sebagai pembuat dan pengurus yang bertanggungjawab;

3. Korporasi sebagai pembuat serta yang bertanggungjawab. ${ }^{34}$

Pada pertanggungjawaban korporasi model pertama, pengurus sebagai pembuat dan pengurus pula yang bertanggungjawab Ketika pengurus tersebut dibebankan kewajiban tertentu yang merupakan kewajiban korporasi, sehingga apabila pengurus itu tidak memenuhi kewajiban tersebut maka dapat diancam pidana, namun dalam model ini termuat alasan penghapus pidana. Tetapi, dalam pertanggungjawaban model ini berangkat dari pemikiran bahwa korporasi tidak dapat dipertanggungjawabkan terhadap suatu pelanggaran dan penguruslah yang melakukan delik. ${ }^{35}$

${ }^{32}$ Sri Septiany Arista Yufeny, 'Pertanggungjawaban Pidana Korporasi Dalam Tindak Pidana Korupsi (Studi Kasus Putusan Nomor 53/Pid.Sus/2012/Pn.Makassar)' (Skripsi Program Sarjana Universitas Hassanudin 2016).[20].

${ }^{33} \mathrm{ibid}$.

${ }^{34} \mathrm{ibid}$.

${ }^{35}$ ibid. 
Dalam model kedua dalam pertanggungjawaban korporasi tersebut, korporasi sebagai pembuat dan pengurus bertanggungjawab, hal ini berangkat dari pemikiran bahwa pengurus merupakan seseorang yang ditunjuk sebagai yang memiliki tanggungjawab kemudian hal yang dipandang dilakukan oleh korporasi merupakan apa yang dilakukan oleh alat perlengkapan korporasi menurut anggaran dasar, sehingga dapat dikatakan bahwa tindak pidana yang dilakukan oleh korporasi merupakan tindak pidana yang dilakukan oleh orang tertentu sebagai pengurus korporasi tersebut, dalam hal ini pula disebut sebagai onpersoonlijk.

Pada pertanggung jawaban korporasi model ketiga, yaitu korporasi sebagai pembuat dan sebagai yang bertanggung jawab, hal ini dikarenakan dalam delik tertentu pemidanaan terhadap pengurus saja tidak cukup dikarenakn tidak dapat menjadi jaminan bahwa korporasi tidak akan melakukan pelanggaran lagi.

di Indonesia muncul pengaturan mengenai Tata Cara Penanganan Perkara Tindak Pidana Oleh Korporasi yang tertuang pada Peraturan Mahkamah Agung Nomor 13 Tahun 2016 yang kemudain dapat disebut PERMA No. 13 Tahun 2016. Peraturan ini ditujukan guna menjawab segala persoalan mengenai sistematika pertanggungjawaban korporasi di Indonesia.

Tidak adanya pengaturan mengenai tata cara pengananan tindak pidana korporasi pada Kitab Undang-Undang Hukum Acara Pidana (KUHAP), maka PERMA No. 13 Tahun 2016 menjadi pelengkap. Mengenai definisi dari korporasi yang diatur dalam Pasal 1 ayat (1) PERMA No. 13 Tahun 2016 adalah korporasi merupakan kumpulan orang dan/atau kekayaan yang terorganisir baik berbentuk badan hukum maupun non badan hukum. ${ }^{36}$ Sedangkan definisi tindak pidana korporasi dalam Peraturan Mahkamah Agung ini adalah tindak pidana yang dilakukan oleh orang berdasarkan hubungan kerja atau hubungan lain, baik sendiri atau bersama-sama yang bertindak atas nama korporasi didalam atau diluar lingkungan korporasi.

Berkaitan dengan pertanggungjawaban klub sepak bola professional di Indonesia berinisial "PSKB" yang membuat dapat diaksesnya informasi mengenai

${ }^{36}$ Peraturan Mahkamah Agung Nomor 13 Tahun 2016 Tentang Tata Cara Penanganan Tindak Pidana Korporasi (Berita Negara Republik Indonesia Tahun 2016 Nomor 2058). 
judi online berinisial " $\mathrm{S}$ " dapat dibebankan kepada pengurus dan/atau korporasi. Hal ini dikarenakan Pasal 23 ayat (1) Perma No. 13 Tahun 2016 tentang Tata Cara Penanganan Perkara Tindak Pidana Oleh Korporasi yaitu "Hakim dapat menjatuhkan pidana terhadap korporasi atau pengurus, atau korporasi dan pengurus." Berdasarkan ketentuan tersebut dapat dimengerti bahwa penjatuhan pidana dapat dilakukan oleh hakim terhadap pengurus atau korporasi baik alternatif maupun kumulatif.

Pasal 1 angka 21 UU ITE mengatur subjek "orang” yang didefinisikan sebagai orang perseorangan, baik warga negara Indonesia, warga negara asing, maupun badan hukum. Kemudian, dalam hal tindak pidana pada undang-undang ini diatur pada Pasal 45-52 UU ITE dengan subjek “orang” maka pertanggung jawaban orang perseorangan sebagai naturlijkpersoon atau badan hukum (rechtpersoon) dimungkinkan dalam UU ITE.embebanan pertanggungjawaban pidana kepada pengurus diatur pada BAB II Huruf B PERJA No. 28 Tahun 2014 yaitu perbuatan pengurus korporasi dapat dimintakan pertanggungjawaban pidana apabila Setiap orang yang melakukan, turut serta melakukan, menyuruh melakukan, menganjurkan melakukan, atau membantu melakukan tindak pidana; Setiap orang yang memiliki kendali dan wewenang untuk mengambil langkah pencegahan tindak pidana tersebut namun tidak mengambil langkah yang seharusnya dan menyadari akan menerima resiko yang cukup besar apabila tindak pidana tersebut terjadi; Setiap orang yang mempunyai pengetahuan akan adanya risiko yang cukup besar cukuplah apabila ia tahu bahwa tindak pidana tersebut dilakukan oleh korporasi; dan/ atau Segala bentuk perbuatan lain yang dapat dimintakan pertanggungjawaban kepada Pengurus Korporasi menurut undang-undang.

Apabila dikaitkan dengan kasus yang ada, maka pengurus dari klub selaku seseorang yang menyuruh lakukan perbuatan pengeksposan segala informasi dan/ atau dokumen elektronik pada website resmi mengenai event yang berkaitan dengan perusahaan judi dan dapat mengarahkan pada dapat diketahuinya informasi mengenai perjudian, hal ini dikarenakan pula pengurus sebagai "directing mind” dari klub.

Kemudian Tindakan pengurus klub sepak bola professional "PSKB" yang tidak mencegah adanya pengeksposan segala hal yang berkaitan dengan perjudian 
dan dapat mengarahkan pada informasi mengenai perjudian sesuai dengan tujuan pemerintah untuk mencegah luasnya tindak pidana perjudian. pengurus juga tidak mengambil Langkah seperti pemutusan kontrak atau tidak menjadikan perusahaan judi online "S" sebagai perusahaan judi online yang tidak memiliki izin di Indonesia sebagai sponsorship dalam Liga 12020.

Aspek berikutnya adalah Setiap orang yang mempunyai pengetahuan akan adanya risiko yang cukup besar cukuplah apabila ia tahu bahwa tindak pidana tersebut dilakukan oleh korporasi. Pengurus sebagai seseorang yang memiliki kendali atas korporasi maka seharusnya ia tahu bahwa pengeksposan terhadap perjudian bertentangan hukum positif di Indonesia, serta perjudian merupakan suatu kejahatan yang berarti merupakan tindakan yang dilarang. Namun, pengurus tidak menghiraukan resiko tersebut. pada Pasal 52 ayat (4) UU ITE yaitu "Dalam hal tindak pidana sebagaimana dimaksud dalam Pasal 27 sampai dengan Pasal 37 dilakukan oleh korporasi dipidana dengan pidana pokok ditambah dua pertiga. " yang kemudian pada penjelasan Pasal tersebut adalah Ketentuan ini dimaksudkan untuk menghukum setiap perbuatan melawan hukum yang memenuhi unsur sebagaimana dimaksud dalam Pasal 27 sampai dengan Pasal 37 yang dilakukan oleh korporasi (corporate crime) dan/atau oleh pengurus dan/atau staf yang memiliki kapasitas untuk:

1. mewakili korporasi;

2. mengambil keputusan dalam korporasi;

3. melakukan pengawasan dan pengendalian dalam korporasi;

4. melakukan kegiatan demi keuntungan korporasi.

Sementara pertangungg jawaban klub sepak bola professional berinisial "PSKB" sebagai badan hukum yang diakui dalam UU ITE sebagai subjek tindak pidana mencerminkan adanya penerapan ajaran identifikasi, hal ini dikarenakan diterimanya pertanggungjawaban pidana korporasi dalam hal pelaku kejahatannya adalah korporasi itu sendiri. ${ }^{37}$ Ajaran identifikasi yang ada dalam undang-undang ini merupakan salah satu teori yang digunakan untuk membenarkan pembebanan pertanggungjawaban korporasi meskipun pada korporasi tidak dapat berbuat

${ }^{37}$ Laila Mulasari, 'Ajaran Pertanggungjawaban Pidana Korporasi Dalam Kebijakan Hukum Pidana di Bidang Mayantara’ (2012) 9 Hukum dan Dinamika Masyarakat.[115]. 
sendiri dan tidak memiliki mens rea. Sehingga, dalam ajaran identifikasi harus memenuhi hal-hal seperti; perbuatan dari personal yang menjadi directing mind korporasi itu termasuk berkaitan dengan kegiatan yang ditugaskan, tindak pidana tersebut bukan merupakan sebuah kecurangan yang dilakukan terhadap korporasi dan tindak pidana tersebut bertujuan untuk menghasilkan keuntungan bagi korporasi yang bersangkutan. ${ }^{38}$

Mengenai penilaian hakim terhadap kesalahan dari korporasi dapat ditinjau dari Pasal 4 PERMA No. 13 Tahun 2016 tentang Tata Cara Penanganan Tindak Pidana Korporasi, yaitu kesalahan korporasi dapat dilihat dari: ${ }^{39}$

1. Korporasi dapat memperoleh keuntungan atau manfaat dari tindak pidana tersebut atau tindak pidana tersebut dilakukan untuk kepentingan Korporasi;

2. Korporasi membiarkan terjadinya tindak pidana; atau

3. Korporasi tidak melakukan langkah-langkah yang diperlukan untuk melakukan pencegahan, mencegah dampak yang lebih besar dan memastikan kepatuhan terhadap ketentuan hukum yang berlaku guna menghindari terjadinya tindak pidana.

Dalam hal hakim dapat menilai kesalahan korporasi diantaranya apabila korporasi memperoleh keuntungan atau manfaat dari tindak pidana tersebut, dan tindak pidana tersebut dilakukan untuk kepentingan korporasi. Hal ini sejalan dengan perbuatan klub sepak bola professional di Indonesia berinisial "PSKB" yang melakukan pengeksposan situs judi online berinsial "S" pada website serta sosial media yang kegiatan tersebut sebagai bentuk kerjasama sponsorship agar klub tersebut mendapatkan keuntungan atau manfaat guna kegiatan operasional klub.

Kemudian, unsur lainnya dalam hal hakim dapat menilai kesalahan korporasi yaitu korporasi dapat membiarkan terjadinya tindak pidana atau korporasi tidak melakukan Langkah-langkah yang diperlukan untuk melakukan pencegahan, mencegah dampak yang lebih besar, serta memastikan kepatuhan terhadap ketentuan hukum yang berlaku guna menghindari terjadinya tindak pidana. Dengan kegiatan

\footnotetext{
38 ibid.

${ }^{39}$ Peraturan Mahkamah Agung, Op.Cit.
} 
pengeksposan situs judi online pada website dan sosial media klub, ini menandakan korporasi mengetahui bahwa situs tersebut memuat informasi mengenai perjudian, namun korporasi membiarkan pengeksposan tersebut terjadi yang kemudian dapat mengarahkan pada dapat diketahuinya informasi mengenai judi, hal ini ditandai dengan tidak adanya Langkah-langkah pencegahan korporasi untuk tidak mengekspos situs tersebut.

Dipenuhinya unsur-unsur tersebut menjadikan korporasi dapat bertanggungjawab secara pidana berdasarkan UU ITE. Pada Pasal 45 ayat (2) UU ITE, tersebut diatur sanksi pidana yang berupa pidana penjara paling lama 6 (enam) tahun dan/atau denda paling banyak Rp 1.000.000.000,00 (satu miliar rupiah) bagi setiap orang yang sengaja dan tanpa hak mendistribusikan dan/atau mentransmisikan dan/atau membuat dapat diaksesnya Informasi Elektronik dan/ atau Dokumen Elektronik yang memiliki muatan perjudian sebagaimana dimaksud dalam Pasal 27 ayat (2) UU ITE.

\section{Kesimpulan}

Pengeksposan yang kemudian berujung pada membuat dapat diaksesnya judi online sebagai sponsor klub tidak memenuhi unsur yang termuat pada KUHP dikarenakan tidak terpenuhinya unsur objektif atau perbuatan "menawarkan atau memberi kesempatan bermain judi”. Namun, Pengeksposan yang membuat dapat diaksesnya situs judi online sebagai sponsor klub sepak bola professional di Indonesia dapat berimplikasi pada tindak pidana berdasarkan UU ITE. Apabila klub melakukan segala kegiatan yang dapat mengakibatkan terhubungnya atau tersalurnya informasi dan/atau dokumen elektronik yang memuat perjudian, hal ini sebagaimana penafsiran abstrak dari bentuk perbuatan "membuat dapat diakses." Dalam penjelasan Pasal 27 UU ITE mengenai "membuat dapat diakses" adalah segala perbuatan selain mendistribusikan dan mentrasnsmisikan, sehingga tidak ada Batasan perbuatan seperti apa yang memenuhi unsur tersebut.

Mengenai tindak pidana yang diatur oleh UU ITE melalui Pasal 45 hingga Pasal 52 UU ITE disebutkan subjek “setiap orang”. Pada ketentuan pasal 1 angka 
21 UU ITE badan hukum diartikan sebagai orang dalam pasal tersebut, sehingga Klub sepak bola professional di Indonesia yang merupakan bentuk badan hukum, diakomodir oleh UU ITE sebagai subjek hukum yang dapat dibertanggungjawab secara pidana. Klub sepak bola professional berinisial "PSKB" maupun pengurus klub dapat bertanggungjawab secara pidana dengan berdasarkan perbuatannya yang memenuhi rumusan pasal 27 ayat (2) jo. Pasal 45 ayat (2) UU ITE. Selain itu, dikarenakan berkaitan dengan pedoman pembebanan pertanggungjawaban pidana korporasi diatur pada PERMA dan PERJA, maka aspek-aspek penilaian kesalahan terhadap korporasi atau pengurus dapat melihat pula ketentuan dalam peraturanperaturan tersebut.

\section{Daftar Bacaan}

\section{Buku}

Adami Chazawi, Ardi Ferdian, Tindak Pidana Informasi \& Transaksi Elektronik (Penyerangan Terhadap Kepentingan Hukum Pemanfaatan Teknologi Informasi Dan Transaksi Elektronik): edisi revisi (Media Nusa Creative 2015).

Mahrus Ali, Dasar-Dasar Hukum Pidana: Cetakan Ketiga (Sinar Grafika 2015).

Peter Mahmud Marzuki, Penelitian Hukum (Kencana Prenada Media Group 2014).

Soetan K. Malikoel Adi, Pembaruan Hukum Perdata Kita (PT Pembangunan 1955).

\section{Jurnal}

Ayya Sofia I, 'Pertanggungjawaban Pidana Pelaku Pendistribusian Konten Yang Bermuatan Asusila Melalui Media Elektronik' (2020) 3 Jurist-Diction.

Claudio Gideon W, Ruddy R. W, Roy R. L, 'Penertiban Perjudian Menurut Peraturan Perundang-Undangan Pidana Indonesia (Analisis Pasal 303 KUHPidana jo. UU No. 7 Tahun 1974)' (2020) 9 Lex. Crimen.

Devy S, Supanto, 'Pengaturan Judi Bola Online Sebagai Tindak Pidana Siber Dalam Hukum Pidana Di Indonesia'(2015) 4 Recidive.

Eko Noer K, 'Mengapa APBD bukan untuk Klub sepak bola professional?' (2016) Rechtsvinding online. 
Geraldy W, 'Kajian Hukum Terhadap Tindak Pidana Perjudian (Penerapan Pasal 303, 303 BIS KUHP)' (2016) 5 Lex Crimen.

Laila M, 'Ajaran Pertanggungjawaban Pidana Korporasi Dalam Kebijakan Hukum Pidana di Bidang Mayantara' (2012) 9 Hukum dan Dinamika Masyarakat.

Muhammad Fajrul F, Fanny T, Samuel SM S, 'Perjudian Online: Kajian Pidana atas Putusan Nomor 1033/PID.B/2014/PN.BDG’ (2017) 4 E-journal Lentera Hukum.

\section{Skripsi}

Imam Dwi W, 'Pertanggungjawaban Pidana Pemilik Website Atas Judi Online Ditinjau Dari Undang-Undang Nomor 11 Tahun 2008 Tentang Informasi dan Transaksi Elektronik', (Skripsi Program Studi Hukum Pidana Fakultas Universitas Islam Bandung 2014).

Sri Septiany Arista Y, 'Pertanggungjawaban Pidana Korporasi Dalam Tindak Pidana Korupsi (Studi Kasus Putusan Nomor 53/Pid.Sus/2012/Pn.Makassar)' (Skripsi Program Sarjana Universitas Hassanudin 2016).

\section{Laman}

Zulfirdaus Harahap, 'Disponsori Situs Judi, Ini Tanggapan Tira Persikabo' ([s.1],2020) <https://www.liputan6.com/bola/read/4185995/disponsori-situsjudi-ini-tanggapan-tira-persikabo $\geq$ accesed 03 September 2020.

[s.n],'Liga2',<https://ligaindonesia.id/clubs?competition=shopee_liga_1_2020>, accesed 19 November 2020.

\section{Peraturan Perundang-undangan}

Undang-Undang Nomor 3 Tahun 2005 Tentang Sistem Keolahragaan Nasional (Lembaran Negara Republik Indonesia Tahun 2005 Nomor 89).

Kitab Undang-Undang Hukum Pidana (Wetboek van Strafrech) (atas pemberlakuan Undang-Undang Nomor 73 Tahun 1958 Tentang Menyatakan Berlakunya Undang-Undang Nomor 1 Tahun 1946 Republik Indonesia Tentang Peraturan Hukum Pidana Untuk Seluruh Wilayah Republik Indonesia, Dan Mengubah KUHP(Lembaran Negara 1958, Tambahan Lembaran Negara1660).

Peraturan Mahkamah Agung Nomor 13 Tahun 2016 Tentang Tata Cara Penanganan Tindak Pidana Korporasi (Berita Negara Republik Indonesia Tahun 2016 Nomor 2058). 